Л.О.Золотухіна

кандидат юридичних наук, дочент, завідувач кафедри иивільно-правових дисииплін Дніпропетровського державного університету внутрішніх справ України

\title{
МЕТОДОЛОГІЯ ДОСЛІДЖЕННЯ ПОНЯТТЯ «ПУБЛІЧНИЙ ІНТЕРЕС» ЯК АДМІНІСТРАТИВНО-ПРАВОВОЇ КАТЕГОРІЇ
}

Дослідження будь-якого правового процесу чи явища потребує відповідного методологічного інструментарію, що зумовлено достатньою складністю об'єктів дослідження, впливом на них значної кількості об'єктивних та суб'єктивних факторів. Поняття «публічний інтерес» є міжгалузевою категорією, що використовується в таких гуманітарних науках, як філософія, політологія, соціологія та юриспруденція зокрема. З огляду на вищезазначене важливим є визначення специфіки методології дослідження поняття «публічний інтерес» як правової категорії та класифікація конкретних наукових методів - інструментарію наукової роботи, який буде використовуватися для доктринального дослідження зазначеного поняття. Значна увага науковців до співвідношення публічних та приватних інтересів у національному законодавстві та юридичній практиці в контексті євроінтеграційних процесів актуалізує проведення цього дослідження, обгрунтовує його теоретичну та практичну значимість.

Методологія дослідження адміністративно-правових категорій досить змістовно розкрита в роботах О. Бандурки, В. Бевзенка, Н. Губерської, С. Гусарова, Р. Калюжного, Т. Коломоєць, В. Колпакова, А. Комзюка, О. Кузьменко, В. Курила, Д. Лук'янця, Д. Лученка, Р. Мельника, О. Миколенка, Н. Нижник, Д. Приймаченка, С. Стеценко, М. Тищенка, А. Школика та інших учених-адміністративістів.

Окремі публікації методології дослідження в юридичній науці загалом та адміністративному праві зокрема присвятили О. Ганьба, В. Мірошниченко «Особливості сучасної методології правових наукових досліджень» [1], А. Благодарний «Методологія дослідження правової регламентації адміністративно-юрисдикційної діяльності правоохоронних органів» [2], В. Ільков «Методологія дослідження джерел права в адміністративному судочинстві» [3], М. Кельман «Методологія сучасного правознавства: становлення та основні напрями розвитку» [4], Н. Кушакова-Костицька «Методологічні проблеми сучасних правових досліджень: об'єктивна необхідність чи суб'єктивна формальність» [5], Г. Лук'янова «Методологічні основи дослідження права у сучасній юридичній науці» [6], В. Пашинський «Методологічний інструментарій дослідження проблем адміністративно-правового забезпечення оборони держави" [7], В. Юровська
«Метод адміністративного права: теоретико-правовий аналіз» [8]. Проте методології дослідження поняття «публічний інтерес» як адміністративно-правової категорії присвячена ще недостатня увага.

Постановка завдання. Метою наукової публікації є визначення інструментарію методології дослідження поняття «публічний інтерес» як адміністративно-правової категорії, що стане науково-методологічною базою для його доктринального дослідження.

Результати дослідження. Починаючи розробку тієї чи іншої юридичної тематики, майже кожен дослідник приділяє увагу методології свого наукового дослідження. Цим зумовлена значна кількість наукових підходів до визначення самого поняття «методологія» в юриспруденції. Тому спочатку доцільно звернутись до енциклопедичного визначення, сформульованого П. Рабіновичем. Так, під методологією юридичної науки він розуміс систему підходів і способів наукового дослідження, теоретичні засади їх використання під час вивчення державно-правових явищ [9, с. 618].

Більш змістовне визначення формулює Д. Голосніченко, на думку якого методологія дослідження в юридичній науці - «це не простий набір певних основоположних понять та категорій, не сукупність прийомів і методів. Це більш ємне поняття. Методологія $є$ теоретичним обгрунтуванням доцільності застосування відповідних підходів і способів, які використовуються для проведення певного теоретико-юридичного дослідження, а також дібрана на науковій основі для зазначеної мети система прийомів і способів, тобто відповідних методів» [10, с. 10].

Отже, методологія юридичної науки є комплексним поєднанням системи конкретних методів дослідження (що включають у себе відповідні наукові підходи, прийоми та способи дослідницької діяльності) та теоретичного обгрунтування необхідності їх застосування для кожного окремого дослідження.

Методологія дослідження будь-якого правового явища чи процесу складається з трьох базових груп методів.

До першої групи методів класично відносять філософські методи діалектики? метафізики, а також принципи об'єктивності та історизму.

Адміністративно-правова категорія «публічний інтерес» діалектично пов'язана із категорією «приватний інтерес». Закон єдності та боротьби 
протилежностей, як один із фундаментальних законів діалектики, є першочерговим інструментом дослідження співвідношення публічних та приватних інтересів.

Єдність цих категорій проявляється у тому, що реалізація та захист публічних інтересів усього суспільства неодмінно сприяє реалізації та захисту приватних інтересів.

Наприклад, публічний інтерес у забезпеченні правопорядку та дотриманні законності співпадає з приватними інтересами більшості громадян у забезпеченні особистої безпеки та спокою. Публічний інтерес організувати систему охорони здоров'я та освіти в державі співпадає з приватними інтересами громадян отримати відповідні послуги належної якості.

Яскравим прикладом прояву протилежності публічних і приватних інтересів є сфера фіскальних відносин. Публічний інтерес держави зібрати максимальну кількість податків вступає в протиріччя з приватними інтересами підприємців мінімізувати суми податків або взагалі уникнути їх сплати.

Публічний інтерес забезпечення безпеки дорожнього руху стикається з приватними інтересами громадян обирати оптимальну швидкість руху, паркуватися у зручних місцях тощо. Публічний інтерес забезпечити обороноздатність держави не співпадає 3 приватним інтересом окремих громадян не проходити військову службу. Публічний інтерес забезпечити суспільну безпеку через існування дозвільної системи не співпадає з приватним інтересом громадян вільно володіти та носити холодну та вогнепальну зброю.

Таким чином, у процесі дослідження адміністративно-правової категорії «публічний інтерес» необхідно активно використовувати такий закон діалектики, як закон єдності і боротьби протилежностей.

Не менше значення для ефективного дослідження категорії «публічний інтерес» має закон «переходу кількісних змін у якісні». Так, збільшення кількості ефективно проведених складників адміністративної реформи веде до підвищення якості публічно-правових відносин, надання адміністративних послуг, що сприяє задоволенню як публічних, так і приватних інтересів учасників цих правовідносин.

Прикладом реалізації закону «переходу кількісних змін у якісні» $€$ якісні зміни в реалізації приватних інтересів у результаті кількісних змін у процесі реалізації публічних інтересів. Наприклад, збільшення кількості викритих та розкритих кримінальних правопорушень, інформація про що оприлюднюється в 3MI, веде до покращення якісних показників соціологічних опитувань щодо підвищення довіри населення до правоохоронних органів, відчуття особистої безпеки, що свідчить про підвищення якості забезпечення та реалізації приватних інтересів окремих громадян. I, навпаки, збільшення кількості реалізованих приватних ін- тересів громадян щодо заняття підприємницькою діяльністю веде до якісних змін у реалізації публічного інтересу суспільства та держави у покращенні інвестиційного клімату, якісному зростанні економічного потенціалу держави тощо.

Застосування такого прийому діалектики, як «заперечення заперечення», під час дослідження «публічного інтересу» проявляється у формі поетапного пошуку (визначення) публічного інтересу в адміністративно-правових відносинах. На першому етапі дослідник заперечує наявність публічного інтересу у певних відносинах, а на другому етапі заперечує своє заперечення, знаходячи докази наявності публічного інтересу у відповідних правовідносинах.

Наприклад, навіть у сімейних правовідносинах, в яких домінує приватний інтерес, держава здійснює адміністративно-правове регулювання, переслідуючи публічні інтереси, зокрема, встановлюючи адміністративно-правову відповідальність за насильство в сім’ї (ст. 173-2 КУпАП).

Принципи об'єктивності та історизму як складники групи філософських методів дослідження необхідно обов' язково застосовувати під час дослідження категорії «публічний інтерес». Принцип об'єктивності передбачає обов'язкове вивчення та аналіз емпіричного матеріалу, проведення репрезентативних соціологічних досліджень 3 метою об'єктивного виявлення елементів публічного інтересу в адміністративно-правовому регулюванні певних правовідносин.

Принцип історизму вимагає від дослідника враховувати історичні обставини та чинники прийняття того чи іншого адміністративного НПА, визначення співвідношення публічних та приватних інтересів у певних історичних умовах, які існували в період здійснення адміністративно-правового регулювання визначених правовідносин. Наприклад, існування адміністративної відповідальності за спекуляцію було цілком виправданим, враховуючи публічні інтереси «радянського» суспільства.

Метод метафізики застосовується в процесі дослідження «публічного інтересу» як адміністративно-правової категорії у разі абстрагування дослідника від будь-яких чинників впливу на предмет правового регулювання i концентрації уваги лише на ознаках публічного інтересу в процесі регулюванні певних суспільних відносин.

Це, наприклад, абсолютизація певних суспільних цінностей, цілей правового регулювання, що може проявлятися, зокрема, під час вирішення питань захисту національної безпеки, пріоритетних національних інтересів. Яскравий приклад - абсолютний пріоритет публічних інтересів та суттєве обмеження інтересів приватних у зоні проведення Операції об'єднаних сил в умовах агресії з боку Російської Федерації.

Другу групу методів дослідження поняття «публічний інтерес» як адміністративно-правової 
категорії становлять загальнонаукові методи дослідження, серед яких: прийоми логічного методу (аналіз, синтез, дедукція та індукція); системний та структурно-функціональний методи; прийоми соціологічного методу (опитування, анкетування), метод статистики.

Системний та структурно-функціональний методи дають змогу розкрити сутність та складники поняття «публічний інтерес», визначити функції кожного елемента. Адже публічний інтерес є системою потреб усього суспільства або значної його частини, які задовольняються за участю суб'єктів владних повноважень у рамках їхньої компетенції у відповідності до чинного законодавства.

Особлива увага в методології дослідження «публічного інтересу» як адміністративно-правової категорії має приділятися прийомам та методам соціологічних досліджень, адже саме встановлення та аналіз поглядів громадян на співвідношення публічних та приватних інтересів в адміністративно-правових відносинах має бути інструментом для визначення пріоритетних напрямів щодо удосконалення правового регулювання цих відносин. Не меншу увагу необхідно приділяти аналізу статистичних даних, які є показником досягнення або недосягнення, часткового досягнення мети правового регулювання, i, зокрема, ступеня реалізації (задоволення) публічних та приватних інтересів.

Третю групу методів дослідження «публічного інтересу» як адміністративно-правової категорії становлять спеціально юридичні методи дослідження, серед яких: метод юридичної догматики (як похідний загальнонаукового аксіоматичного методу); методи порівняльного правознавства; методи герменевтики (тлумачення НПА) та метод юридичного моделювання.

Прикладом застосування методу юридичної догматики є трактовка (інтерпретація) «публічного інтересу» в контексті положень ст. 3 Конституції України, які по суті є юридичною догмою (аксіомою): «Людина, її життя і здоров’я, честь i гідність, недоторканість і безпека визнаються в України найвищою соціальною цінністю. Права і свободи людини та їх гарантії визначають зміст і спрямованість діяльності держави» [11].

Таким чином, у Конституції України фактично закріплено, що приватні інтереси людей в Україні визначають спрямованість та зміст публічних інтересів держави.

Важливим є використання методів порівняльного правознавства для дослідження співвідношення публічних і приватних інтересів у сфері адміністративно-правового регулювання суспільних відносин у зарубіжних країнах. У цьому контексті особливо актуальним є дослідження практики Свропейського суду з прав людини, рішення якого є джерелом права в Україні (ст. 17 Закону України «Про виконання рішень та застосування практи- ки Свропейського суду з прав людини» [12]), адже саме в прецедентах Свропейського суду з прав людини уніфікується підхід до визначення оптимального співвідношення приватних і публічних інтересів, встановлюються їх межі. Відповідні рішення імплементуються в національне законодавство та юридичну практику країн-членів Ради Європи, що фактично створює нове загальноєвропейське право. Таким чином, використання методів порівняльного правознавства дає змогу запозичити та імплементувати встановлені Європейським судом з прав людини моделі співвідношення приватних і публічних інтересів у національне законодавство та юридичну практику з метою попередження порушення норм європейської Конвенції про захист прав людини і основоположних свобод в Україні.

Суттєве значення для змістовного та результативного дослідження категорії «публічний інтерес» має метод юридичного моделювання, який використовується в процесі створення нових правових конструкцій, моделей правовідносин, формулювання конкретних пропозицій щодо удосконалення чинного та формування перспективного законодавства.

Зокрема, в сфері регулювання адміністративно-правових відносин за допомогою методу юридичного моделювання створюються оптимальні нормативні конструкції, в яких досягається максимальний баланс між публічними та приватними інтересами.

Наприклад, моделювання проєкту перспективного Адміністративно-процедурного кодексу України має забезпечити реалізацію як публічного інтересу у досконалому врегулюванні відповідних правовідносин, так і приватних інтересів громадян в отриманні єдиного та універсального адміністративно-процедурного акта, який стане ефективним інструментом взаємодії між громадянами та органами публічної адміністрації, сприятиме ефективній реалізації прав і свобод людини.

Підсумовуючи, слід зазначити, що філософські, загальнонаукові та спеціально юридичні методи дослідження «публічного інтересу» як адміністративно-правової категорії необхідно застосовувати в органічному поєднанні, шукаючи оптимальні шляхи вирішення поставлених задач. Результатом дослідження мають бути не тільки загальнотеоретичні конструкції та висновки, а практичні пропозиції щодо удосконалення чинного законодавства та юридичної практики у сфері адміністративно-правового регулювання суспільних відносин, пов'язаних із публічним інтересом.

Так, у контексті євроінтеграційних процесів особливої актуальності набуває визначення специфіки методології дослідження співвідношення публічних та приватних інтересів в адміністративному праві. Основними суб'єктами, які нині визначають вказане співвідношення, є адміністративні суди, Верховний Суд, а також Європейський 
суд з прав людини. Кожен Правовий висновок Верховного Суду, кожне Рішення Європейського суду з прав людини $€$ по суті новою моделлю співвідношення приватних та публічних інтересів, тому, досліджуючи відповідні прецеденти, доцільно використовувати метод юридичного моделювання 3 метою формування нової юридичної конструкції співвідношення приватних і публічних інтересів, яка випливає зі змісту правової позиції відповідної судової інституції. Але, моделюючи нову норму права на основі судового прецеденту, слід використовувати і метод юридичної догматики, який зобов'язує враховувати фундаментальні принципи права та юридичні аксіоми щодо верховенства права, примату міжнародного права над національним, визнання прав і свобод людини найвищою соціальною цінністю тощо. Крім того, враховуючи євроінтеграційні процеси, необхідно активно використовувати методи порівняльного правознавства, запозичуючи найкращий досвід правової регламентації співвідношення публічних та приватних інтересів у державах-членах Європейського Союзу.

Таким чином, для ефективного дослідження поняття «публічний інтерес» як адміністративно-правової категорії та його співвідношення із поняттям «приватного інтересу» пріоритетними у застосуванні є методи юридичної догматики, юридичного моделювання, а також методи порівняльного правознавства з акцентом на європейські правові цінності.

Висновки. Методологія дослідження поняття «публічний інтерес» як адміністративно-правової категорії має грунтуватися на органічному поєднанні філософських, загальнонаукових та спеціально юридичних методів дослідження, а також принципів об'єктивності та історизму. Специфіка методології дослідження співвідношення публічних та приватних інтересів в адміністративному праві полягає у пріоритетному застосуванні спеціально юридичних методів юридичної догматики та юридичного моделювання, адже, попри існування визначених правових аксіом (верховенство права, примат міжнародного права, пріоритетність прав і свобод людини в механізмі правового регулювання), завданням як науковців, так і практиків $€$ пошук та моделювання оптимального співвідношення приватних та публічних інтересів у сфері адміністративно-правових відносин. Яскравим прикладом такого моделювання є Правові висновки Верховного Суду, прецеденти Європейського суду з прав людини, в яких визначаються межі втручання держави у сферу приватних інтересів, а також підстави, умови та ступінь обмеження приватних інтересів задля забезпечення реалізації та захисту публічних інтересів суспільства та держави.

Перспективність подальшого дослідження цієї теми зумовлена необхідністю змістовного аналізу теоретико-методологічної основи категорії «публічний інтерес» у доктрині адміністративного права, а саме дослідження методологічних підходів до розуміння поняття «публічний інтерес» різними науковими школами адміністративного права як в історичному контексті, так і сучасними вітчизняними та зарубіжними науковцями.

\section{Jimepamypa}

1. Ганьба О.Б., Мірошніченко В.I. Особливості сучасної методології правових наукових досліджень. Парадигма пізнання: гуманітарні питання. № 2 (13). 2016. C. $1-13$.

2. Благодарний А. Методологія дослідження правової регламентації адміністративно-юрисдикційної діяльності правоохоронних органів. Підприємниитво, господарство і право. № 6. 2018. С. 147-151.

3. Ільков В.В. Методологія дослідження джерел права в адміністративному судочинстві. Форум права. № 5. 2016. C. 48-52.

4. Кельман М. Методологія сучасного правознавства: становлення та основні напрями розвитку. Психологія і суспільство. № 4. 2015. С. 33-46.

5. Кушакова-Костицька Н.В. Методологічні проблеми сучасних правових досліджень: об'єктивна необхідність чи суб'єктивна формальність. Філософські та методологічні проблеми права. № 1-2. 2013. С. 23-31.

6. Лук'янова Г.Ю. Методологічні основи дослідження права у сучасній юридичній науці. Науковий вісник Львівського державного університету внутрішніх справ. № 4. 2011. С. 33-43.

7. Пашинський В.Й. Методологічний інструментарій дослідження проблем адміністративно-правового забезпечення оборони держави. Вісник Національного технічного університету України "Київський політехнічний інститут». Політологія. Соціологія. Право. № 3-4. 2017. С. 98-102.

8. Юровська В. Метод адміністративного права: теоретико-правовий аналіз. Підприємництво, господар ство і право. № 12. 2017. С. 188-192.

9. Рабінович П.М. Методологія юридичної науки. Юридична енциклопедія: в 6 т. / голова редкол. Ю.С. Шемшученко. Київ : Вид-во Українська енциклопедія імені М.П. Бажана, 1998-2004. Т. 3: К-М. 2001. 789 с.

10. Голосніченко Д.І. Теорія Повноважень: вітчизняний та зарубіжний досвід їх формування : монографія. Київ : Г.А.М., 2009. 356 с.

11. Конституція України від 28.06.1996 р. № $254 \mathrm{\kappa} / 96$-BP. Дата оновлення: 21.02 .2019 p. URL: https://zakon.rada.gov.ua/laws/show/254к/96-вр.

12. Про виконання рішень та застосування практики Європейського суду з прав людини : Закон України від 23.02.2006 р. № 3477-IV. Дата оновлення: 02.12.2012 p. URL: https://zakon.rada.gov.ua/laws/show/3477-15.

\section{Анотація}

Золотухіна Л. О. Методологія дослідження поняття "публічний інтерес» як адміністративно-правової категорії. - Стаття.

У науковій публікації досліджується система наукових підходів, прийомів та способів дослідження поняття «публічний інтерес» як адміністративно-правової категорії. Визначається специфіка методології дослідження співвідношення публічних та приватних інтересів в адміністративному праві з метою удосконалення їх правової регламентації.

Актуальність розробки цієї теми обгрунтовується тим, що дослідження будь-якого правового процесу чи явища потребує відповідного методологічного інструментарію, що зумовлено достатньою складністю об'єктів 
дослідження, впливом на них значної кількості об’єктивних та суб'єктивних факторів. Поняття «публічний інтерес» є міжгалузевою категорією, що використовується в таких гуманітарних науках, як філософія, політологія, соціологія та юриспруденція зокрема. Отже, важливим $\epsilon$ визначення специфіки методології дослідження поняття «публічний інтерес» як правової категорії та класифікація конкретних наукових методів - інструментарію наукової роботи, який буде використовуватися для доктринального дослідження зазначеного поняття.

Відзначається, що методологія дослідження поняття «публічний інтерес» як адміністративно-правової категорії має грунтуватися на органічному поєднанні філософських, загальнонаукових та спеціально юридичних методів дослідження, а також принципів об'єктивності та історизму. Специфіка методології дослідження співвідношення публічних та приватних інтересів в адміністративному праві полягає у пріоритетному застосуванні спеціально юридичних методів юридичної догматики та юридичного моделювання, адже, попри існування визначених правових аксіом (верховенство права, примат міжнародного права, пріоритетність прав і свобод людини в механізмі правового регулювання), завданням як науковців, так і практиків є пошук та моделювання оптимального співвідношення приватних та публічних інтересів у сфері адміністративно-правових відносин. Яскравим прикладом такого моделювання є Правові висновки Верховного Суду, прецеденти Європейського суду з прав людини, в яких визначаються межі втручання держави у сферу приватних інтересів, а також підстави, умови та ступінь обмеження приватних інтересів задля забезпечення реалізації та захисту публічних інтересів суспільства та держави.

У контексті євроінтеграційних процесів велике значення має використання методів порівняльного правознавства з акцентом на європейські правові цінності.

Ключові слова: методологія, науковий підхід, публічний інтерес, адміністративне право, доктрина, методи дослідження, моделювання, система.

\section{Summary}

Zolotukhina L. O. Methodology for the study of the concept of "public interest" as an administrative-legal category. - Article.

The scientific publication analyzes the system of scientific approaches, methods and ways of studying the concept of «public interest» as an administrative law cat- egory. The specificity of the research methodology of the relationship between public and private interests in administrative law is determined in order to improve their legal regulation.

The importance of this publication is justified by the fact that the study of any legal process or phenomenon requires appropriate methodological tools, due to the sufficient complexity of the objects of study, the influence on them of a significant number of objective and subjective factors. The concept of «public interest» is an interdisciplinary category, which is used in such humanities as philosophy, political science, sociology, and jurisprudence in particular. Consequently, it is important to determine the specificity of the methodology of researching the concept of «public interest» as a legal category and the classification of specific scientific methods - tools of scientific work, which will be used for the doctrinal research of this concept. It is noted that the methodology for the study of the concept of "public interest» as an administrative-legal category should be based on an organic combination of philosophical, general scientific and special legal methods of research, as well as the principles of objectivity and historicism. The specificity of the methodology of researching the correlation of public and private interests in administrative law consists in the priority application of methods of legal dogma and legal modeling. Despite the existence of certain legal axioms (the rule of law, the primacy of international law, the priority of human rights and freedoms in the mechanism of legal regulation), the task of both scholars and practitioners is to search for and model the optimal balance of private and public interests in the field of administrative law.

A striking example of such modeling is the Legal Conclusions of the Supreme Court, the precedents of the European Court of Human Rights, which define the boundaries of state intervention in the sphere of private interests, as well as the grounds, conditions and degree of restriction of private interests to ensure the implementation and protection of the public interests of society and the state.

In the context of European integration processes, it is important to use methods of comparative law with a focus on European legal values.

Key words: methodology, scientific approach, public interest, administrative law, doctrine, research methods, modeling, system. 